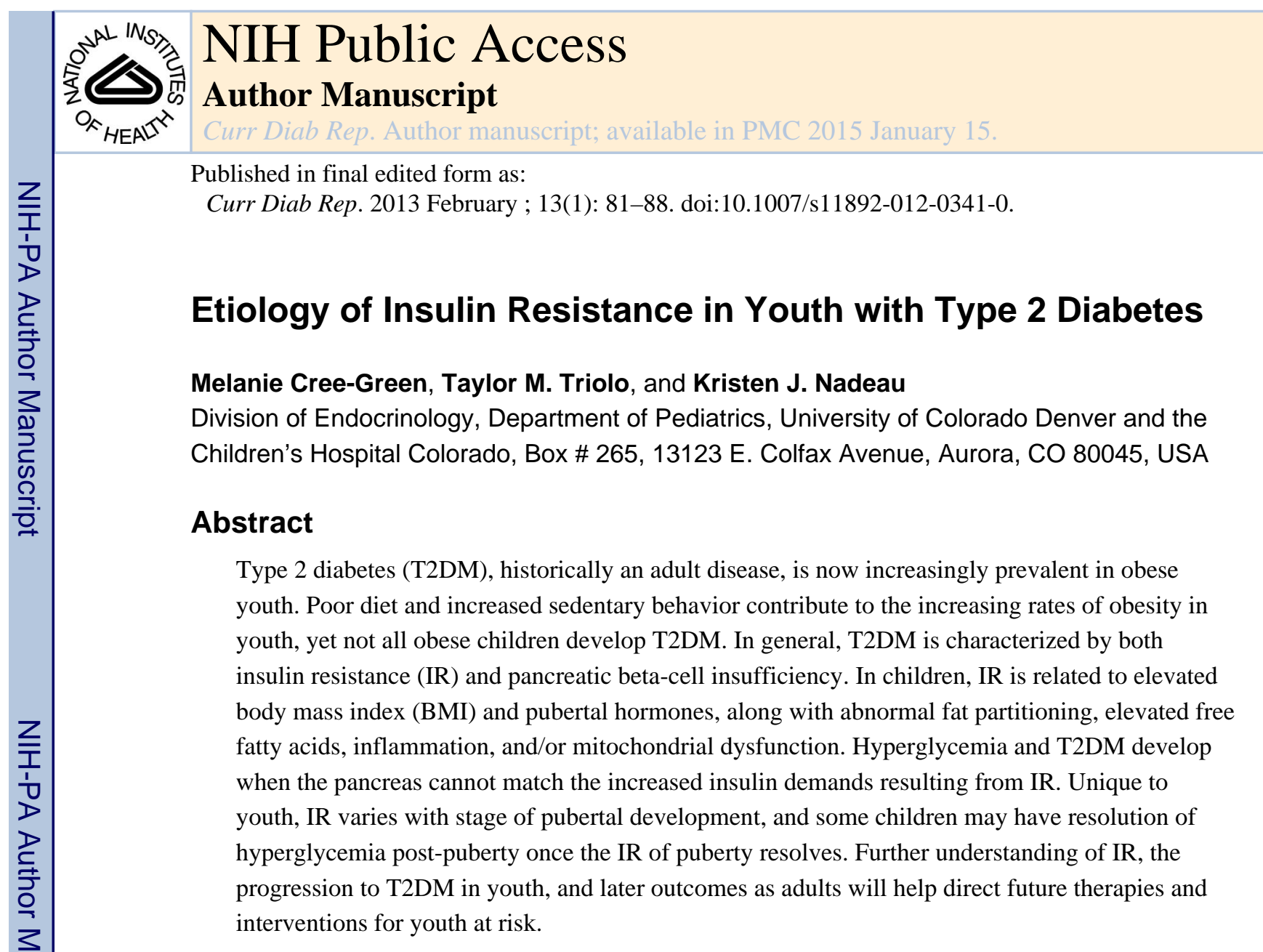

Keywords

Type 2 diabetes; Insulin resistance; Pediatrics; Obesity

\title{
Introduction
}

Type 2 diabetes mellitus (T2DM) was once thought to be a disease exclusive to adults. However, as rates of obesity in children have risen, the prevalence of pediatric T2DM has also increased [1-3]. T2DM is caused by the combination of insulin resistance (IR), defined as dysfunctional cellular response to insulin combined with pancreatic beta-cell insufficiency. IR, thought to be the initial defect, also underlies the metabolic syndrome. The metabolic syndrome is a cluster of obesity-associated conditions, including dyslipidemia, fatty liver disease, and hypertension, that puts youth at risk for cardiovascular disease [4, 5]. This is especially concerning, as recent reports have indicated that average life expectancy drops by approximately 15 years when adolescents develop T2DM, and chronic complications may occur by the age of 40 [6•]. Multiple factors play a role in the progression from IR to T2DM in youth. It is well known that insulin sensitivity decreases in puberty due to increases in growth hormone, testosterone, and estrogen secretion, and

\footnotetext{
(c) Springer Science+Business Media New York 2012

M. Cree-Green Melanie.Green@ childrenscolorado.org.

T. M. Triolo Taylor.triolo@ucdenver.edu

K. J. Nadeau Kristen.Nadeau@childrenscolorado.org
} 
increases fat mass. Our modern, sedentary, high-calorie lifestyle has contributed to the increase in obesity rates overall, but the youth who develop IR or T2DM seem to store this excess lipid in different locations than obese youth who remain insulin sensitive [1]. It may also be that this alternate lipid storage is affected by fetal exposure to maternal obesity or diabetes, and early neonatal feeding patterns $[7,8 \bullet \bullet$. This review will focus on the unique aspects of IR in progression of T2DM in youth and the lifestyle and molecular mechanisms that contribute to IR in this population.

\section{Assessment of Insulin Resistance in Children}

The gold standard to measure insulin sensitivity is the hyperinsulinemic euglycemic clamp, as exogenous insulin administration bypasses reliance on pancreatic insulin release $[4,9$, 10]. However, accurate assessment of IR in children is difficult as there are limited normative data and the dynamic relationship between glucose homeostasis and pancreatic beta-cell function is influenced by factors such as exercise, menstrual cycle, diet, and puberty [11,12]. Using hyperinsulinemic euglycemic clamps, we and others have demonstrated IR in obese, non-diabetic adolescents, and markedly decreased insulin sensitivity in obese, T2DM adolescents [9, 13]. A simpler yet still valid measurement of insulin sensitivity and secretion in individuals with intact beta cells is the frequently sampled intravenous glucose tolerance test (IVGTT) [4]. Hyperinsulinemic clamps and the IVGTT are both labor intensive, somewhat invasive, and costly modalities that are not practical for use in large scale studies for screening. Therefore, surrogate markers are often used. The OGTT-derived whole body insulin sensitivity index and the ratio of glucose and insulin ratios under the curve correlate well with clamp-derived IR in youth, but less so with fasting indices [10,14]. However, once insulin secretion is decreased, OGTT and IVGTT assessments become problematic, and require further calculations. The product of beta-cell function and insulin sensitivity is the disposition index (DI), which quantifies insulin secretion relative to insulin sensitivity [15]. DI has been shown to predict development of T2DM in adult and adolescent longitudinal studies, with T2DM occurring after beta-cell failure [16••, 17]. A comparison of OGTT-derived DI (oDI) and clamp-derived DI (cDI) in adolescents demonstrated that oDI correlated well with cDI especially among subjects with IGT [16••]. Thus, oDI may be used as an estimate for IR when clamps are not available or feasible, and there is a suspicion of insufficient insulin secretion.

Fasting measures of IR are problematic. Fasting insulin tests must be truly fasting and due to assay variability can only be compared with results run in the same laboratory, making the creation of universal norms difficult. The homeostasis model assessment of IR (HOMAIR) is a IR surrogate widely used for population-based studies that uses fasting insulin and glucose but is only marginally better or even inferior to fasting insulin alone in children [4, 18]. In addition, due to the variability of IR through puberty, a normative range for children is not clear, though a recent study of 6100 children in Mexico reported age-based pediatric HOMA-IR norms as they change throughout childhood, similar to that used for BMI and blood pressure [19•]. Finally, as is the case for the OGTT and IVGTT, measures based on fasting insulin become invalid once insulin secretion is defective, as is the case in IGT, IFG, and T2DM [4, 9]. Alternatively, the fasting triglyceride:HDL ratio has been correlated with insulin suppression-based IR assessment in adults, but has yet to be validated in children 
[20]. In addition, using waist circumference, $\mathrm{HbA1c}$ and triglyceride data, we recently developed an estimate of clamp-based IR in youth for application to large epidemiologic studies, but further research as to its predictive value for long term outcomes is still required [21].

\section{Mechanisms of Insulin Resistance in Children with T2DM}

As in adults, IR is thought to be related to the interaction between abnormal fat and glucose metabolism. A Japanese study of children with T2DM showed that OGTT-derived IR correlated with the degree of overall obesity [22]. Abnormal fat partitioning, with increased visceral, hepatic, and intramyocellular lipids and elevated BMI are related to IR in adults [1, 2, 23]. Similarly this relationship between IR and increased visceral, hepatic and intramyocellular lipids are seen in youth with prediabetes and T2DM [13, 24-26]. In obese youth with normal glucose tolerance, increased muscle, hepatic, and visceral fat are also related to the degree of IR [27]. Youth with T2DM can have up to 3 times the amount of liver fat compared with BMI-matched nondiabetic controls [1]. Similarly, youth with nonalcoholic fatty liver disease (NAFLD) have hepatic and peripheral IR as demonstrated by hyperinsulinemic euglycemic clamps [28]. In obese youth with NAFLD, the severity of liver disease is also related to the degree of IR [29]. It is not clear if hepatic steatosis precedes IR, but is known that NAFLD is a strong risk factor for IGT, IFG, and T2DM [1, 13, 25]. However, it is important to remember that not all obese youth go on to develop T2DM, and this data suggests that early storage of fat in the liver, viscera and muscle increases risk of development of T2DM. In addition, genetic factors likely influence the location of storage of excess lipid.

Increased ectopic fat storage may also be related to increased levels of plasma free fatty acids (FFA) which can also directly decrease insulin sensitivity. Excessive processing of nutrients, including FFA by mitochondria may result in an increase of reactive oxygen species (ROS) due to uncoupling of oxidative phosphorylation which in turn leads to altered mitochondrial function and to production of more ROS [30]. These ROS can then lead to endoplasmic reticulum dysfunction and thus defective insulin secretion in pancreatic beta cells [31]. ROS, and/or lipid byproducts may also impair insulin signaling cascades. Obese children are reported to have increased FFA concentrations, related to their degree of IR [32]. Muscle mitochondrial dysfunction in individuals with T2DM has been shown to be associated with muscle IR [33]. A study in obese children found that obesity, per se, was not related to mitochondrial function, but that those with obesity and IR had prolonged ATP synthesis following exercise, a marker of mitochondrial dysfunction [34]. Muscle and hepatic IR is also mediated by peroxisome proliferator-activated receptor (PPAR) receptors, as evidenced by the use of PPAR-y agonists for the treatment of T2DM. In some individuals with T2DM, there may be genetic alterations in PPAR-y expression, mitochondrial function, and/or inflammation related to IR [35], arguing that obesity-induced FFA elevations in genetically predisposed individuals are a primary cause of pediatric T2DM.

Part of the variability in insulin sensitivity in obese adolescents is likely related to hormonal changes in puberty. Growth hormone, estrogen, and androgens can all affect insulin sensitivity [36-38]. Studies have monitored the changes in insulin sensitivity in healthy 
children throughout the progression of puberty. These studies show that IR starts prior to puberty, even before rises in pituitary gonadotropin secretion, and is partly explained by the accumulation of fat and rising insulin-like growth factor 1 (IGF-1) [12]. IR peaks when children are in mid-puberty, equivalent to Tanner stage 3-4, and decreases at the conclusion of puberty [39], at least in normal-weight youth. These unique, fluctuating influences on IR, which can vary by time of day and time during menstrual cycle in girls, maybe a large reason that the diagnosis of IR, IGT, and IFG can be so challenging to reproduce in adolescents.

\section{The Role of Lifestyle Factors on Development of T2DM}

The recent increase in obesity rates has become a costly public health problem. The link between obesity and T2DM has been well reported through many epidemiologic studies [40]. Most studies have focused on the degree of obesity, using BMI as a marker for risk to development of diabetes [41]. The duration of obesity may be equally important as a risk factor for T2DM. Independent of absolute BMI, longer obesity duration is associated with T2DM [42, 43]. The tripling of obesity rates in children over the last 30-40 years implies that the length of time that people will spend obese has also increased. Studies show that time spent at a BMI greater than the $85^{\text {th }}$ percentile is associated with an increased risk of diabetes [44]. Pubertal IR requires additional insulin secretion to maintain normoglycemia, and superimposed obesity may create too large of a demand on the pancreas in susceptible individuals. Furthermore, obesity, once established, is difficult to reverse. Therefore, being obese at puberty may be especially detrimental. Thus, early interventions, prior to puberty, may be most helpful in preventing the development of T2DM and its complications [45]. Efforts to quell obesity in the very young show promise, as youth at risk for behavior problems who received family intervention at age 4 had a lower BMI and improved health behaviors as they reached adolescence [46].

A sedentary lifestyle is also critical to development of T2DM in youth. There has been a dramatic recent decrease in overall physical activity level, especially in girls, during the transition from childhood to adolescence [47], the time at which overweight youth are at great risk for developing T2DM. Of note, T2DM youth are even more obese and sedentary than T2DM adults $[48,49]$. A sedentary lifestyle and low cardiorespiratory fitness are associated with IR, IFG, and T2DM $[13,50]$. This predisposing factor is especially important to understand, as once T2DM develops, diabetes itself appears to impair cardiorespiratory fitness, which may further reduce physical activity level [13]. Participation in physical activity can prevent or delay the onset of T2DM and improve blood glucose control in adults [51]. Additionally, in children with a family history of obesity, physical activity is associated with increased insulin sensitivity, independent of level of fitness, or sedentary behavior [52•]. However, in the recently published TODAY study of T2DM youth, an intensive lifestyle intervention including physical activity was unable to decrease treatment failure when added to metformin, arguing that exercise and dietary changes are difficult to make in youth with established T2DM [53]. Therefore, it appears especially important for youth to maintain a physical activity regimen early in life. 
The rise in obesity, metabolic syndrome, and diabetes has increased in conjunction with the rise in daily caloric intake [54]. In particular, a western diet high in total fat, saturated fatty acids, and refined grains has been associated with increased risk for metabolic syndrome [55]. In contrast, risk for metabolic syndrome is decreased with diets high in fruits, vegetables and whole grains [56, 57]. In addition, Mediterranean diets high in monounsaturated and polyunsaturated fats and fiber reduced the risk for metabolic syndrome in a controlled clinical trial [58]. The Dietary Intervention Study in Children (DISC) evaluated the effects of a low fat, high fiber diet during adolescence and showed benefit in both glycemic control and blood pressure [59]. A ketogenic very low calorie diet sustained for 60 days can also improve BMI and blood glucose control in children with T2DM [60].

In addition to the effect of childhood diet and activity, the development of IR and obesity may also be influenced by the in utero environment, and by feeding patterns and weight gain in the first year of life. It is known that both low and high birth weight predict metabolic abnormalities later in life [61]. In children exposed to gestational diabetes mellitus (GDM) in utero, the BMI velocity from ages $6-12$ is increased [8••]. The risk of metabolic syndrome by age 11 years in children born large for gestational age to GDM mothers was 3.6 times greater than those born average for gestational age to GDM mothers, and maternal obesity, regardless of birth size, increased the risk twofold [7]. Increased maternal BMI prior to conception was also associated with increased neonatal hepatic fat content [62]. At 1 year of age, infants whose mothers had GDM had higher plasma triglycerides, and glucose area under the curve during an OGTT compared with infants from mothers without GDM [63]. IR in these infants was associated with increased weight gain in the first year of life. Furthermore, children who were breastfed at least 6 months in infancy were more likely to be in to be lean and have lower percentages of visceral and subcutaneous adipose tissue [64]. While the mechanisms of these changes require further study, it is likely that changes we are currently seeing in pediatrics may be "second generation" effects of the obesity epidemic which started 30-40 years ago.

\section{Unique Aspects of Progression from Insulin Resistance to T2DM in Children}

The progression from IR to IGT/IFG to T2DM is regulated by the relationship between IR and insulin secretion [65]. Hyperglycemia develops once the beta cell insulin secretion is inadequate to match the level of IR $[1,66,67]$. In children, the rate of conversion from IGT/IFG to T2DM appears faster compared with adults and can occur over the span of 1221 months $[1,68,69 \bullet \cdot]$. Adults who are IR lose an average of $7 \%$ of their beta cells per year [66]. Case reports have detailed the progression of a child to development of T2DM with a rate of beta-cell deterioration at about $15 \%$ per year [70]. Secretion of insulin is dependent on beta-cell mass and secretory capacity, that are both governed by genetic and environmental factors, including increased FFA levels [1, 66, 71]. A recent study of 700 children found that higher fasted plasma concentrations of FFA were related to decreased first phase insulin secretion following a glucose load [72]. Once IR-induced hyperglycemia develops, inflammation caused by hyperglycemia may promote further apoptosis of beta cells [73]. In longitudinal pediatric population studies, IR worsens already damaged beta 
cells $[29,74]$, and cross sectional studies show that children who progress to T2DM have lower insulin levels [67]. In obese youth a $>30 \%$ decline in cDI is already apparent at the upper end of normal glucose tolerance (NGT; $120-140 \mathrm{mg} / \mathrm{dl}$ ) [75]. Furthermore, with a 1 hour OGTT glucose $>155 \mathrm{mg} / \mathrm{dl}$, obese youth have a lower DI even if they are NGT at 2 hours [76]. Although overall insulin secretory capacity is greater in youth, and first phase insulin secretion is higher in T2DM youth compared with T2DM adults, there is a step-wise decline in first and second-phase insulin secretion from NGT to IGT to T2DM in obese adolescents $[68,77 \cdot]$.

In contrast to adults with IR, not every obese adolescent with hyperglycemia goes on to develop T2DM. In a cohort of 75 NGT obese adolescents, increased baseline HbA1c and weight gain predicted progression to IGT [77•]. Among 218 obese youth, HbA1c at baseline and 2 hour OGTT level at baseline predicted an increase in 2 hour OGTT. HbA1c $>5.7 \%$ predicted later IGT or T2DM [78]. In a study of 117 obese youth, at baseline 84 had NGT, and 33 had IGT. $30.3 \%$ of those with IGT returned to NGT, and only $8 \%$ progressed to T2DM. Severe obesity, IGT, and African American background were the best predictors of developing T2DM [79]. Another study prospectively followed 79 obese white children and adolescents with IGT. $32 \%$ of children after 1 year continued to be IGT, but $66 \%$ converted to NGT. Predictive factors for normalization of IGT were lower weight, HbAlc, 2 hour OGTT glucose at baseline, weight loss, and entering late puberty during follow-up [69••]. In the 3- to 5-year follow-up, $16 \%$ were still IGT, $75 \%$ converted to NGT, and $2 \%$ developed T2DM. Higher 2 hour OGTT level at baseline and weight gain were predictors for remaining at IGT [80]. Some youth, especially Caucasian, or in later stages of puberty, may not progress to overt T2DM.

We propose that there are 4 overall phenotypes of children, as shown in Fig. 1a-d. In lean children (Fig. 1a), insulin sensitivity decreases with puberty, and is matched by adequate upregulation of pancreatic insulin secretion. In obese children (Fig. 1b) with no family history of T2DM and minimal abnormalities in fat partitioning, there is decreased insulin sensitivity, and again adequate pancreatic up-regulation in insulin secretion through puberty. In those obese children with some alteration in fat partitioning (Fig. 1c), insulin sensitivity also decreases through puberty, and at the nadir of insulin sensitivity, insulin secretion is inadequate, leading to IGT or IFG. However as they complete puberty, insulin sensitivity recovers and their hyperglycemia resolves as their pancreas can again meet the insulin demands. It may be that the transient IGT seen in these teens is similar to that of GDM, implying that these teens will be at increased risk of diabetes later in life, compared with obese teens with no IGT. Finally, in those children who develop T2DM (Fig. 1d), decreased insulin sensitivity and the stress on the pancreas leads to a rapid decline in beta-cell function, so that even as their insulin sensitivity increases after puberty, permanent pancreatic insufficiency continues, and they remain with hyperglycemia into adulthood.

\section{Conclusions}

In conclusion, pediatric obesity, IR, and T2DM are steadily increasing in prevalence worldwide. Lifestyle factors, including decreased physical activity and diets high in simple carbohydrates and fat, play a major role in the development of IR in obese youth. In youth

Curr Diab Rep. Author manuscript; available in PMC 2015 January 15. 
with a combination of genetic predisposition, in utero exposure to maternal obesity or diabetes, or breastfeeding less than 6 months, this obesity may be associated with abnormal lipid partitioning and potentially beta-cell failure. Insulin sensitivity decreases as children go through puberty, but typically improves once puberty is completed. Not all children with IR go on to develop T2DM, as some return to euglycemic levels. Identifying those youth who will progress to T2DM will be important for targeting therapies and interventions.

\section{References}

Papers of particular interest, published recently, have been highlighted as:

- Of importance

•• Of major importance

1. D’Adamo E, Caprio S. Type 2 diabetes in youth: epidemiology and pathophysiology. Diabetes Care. 2011; 34(Suppl 2):S161-5. [PubMed: 21525449]

2. Arslanian S, Suprasongsin C. Insulin sensitivity, lipids, and body composition in childhood: is "syndrome X" present? J Clin Endocrinol Metab. 1996; 81(3):1058-62. [PubMed: 8772576]

3. Ogden, C.; Carroll, M.; Kit, B.; Flegal, K. Prevalence of obesity in the United States, 2009-2010 NCHS data brief, no 82. National Center for Health Statistics; Hyattsville. MD: 2012.

4. Levy-Marchal C, Arslanian S, Cutfield W, Sinaiko A, Druet C, Marcovecchio ML, et al. Insulin resistance in children: consensus, perspective, and future directions. J Clin Endocrinol Metab. 2010; 95(12):5189-98. [PubMed: 20829185]

5. Lee S, Bacha F, Gungor N, Arslanian S. Comparison of different definitions of pediatric metabolic syndrome: relation to abdominal adiposity, insulin resistance, adiponectin, and inflammatory biomarkers. J Pediatr. 2008; 152(2):177-84. [PubMed: 18206686]

6•. Rhodes ET, Prosser LA, Hoerger TJ, Lieu T, Ludwig DS, Laffel LM. Estimated morbidity and mortality in adolescents and young adults diagnosed with Type 2 diabetes mellitus. Diabet Med. 2012; 29(4):453-63. [PubMed: 22150528] This is a statistical modeleing paper which evaluated the rate of development of adult type 2 co-morbities, and applied them to children who develop diabetes. The model predicts an estimated 15 year shorter life span, and complicatons developing in the $4^{\text {th }}$ decade of life.

7. Boney CM, Verma A, Tucker R, Vohr BR. Metabolic syndrome in childhood: association with birth weight, maternal obesity, and gestational diabetes mellitus. Pediatrics. 2005; 115(3):e290-6. [PubMed: 15741354]

8••. Crume TL, Ogden L, Daniels S, Hamman RF, Norris JM, Dabelea D. The impact of in utero exposure to diabetes on childhood body mass index growth trajectories: the EPOCH study. J Pediatr. 2011; 158(6):941-6. [PubMed: 21238981] This is a longitudinal cohort of US children with detailed gestational information. Those with in utero exposure to diabetes had a greater BMI growth velocity through childhood, compared to those who were not exposed to maternal diabetes.

9. Yeckel CW, Weiss R, Dziura J, Taksali SE, Dufour S, Burgert TS, et al. Validation of insulin sensitivity indices from oral glucose tolerance test parameters in obese children and adolescents. J Clin Endocrinol Metab. 2004; 89(3):1096-101. [PubMed: 15001593]

10. Henderson M, Rabasa-Lhoret R, Bastard JP, Chiasson JL, Baillargeon JP, Hanley JA, et al. Measuring insulin sensitivity in youth: How do the different indices compare with the goldstandard method? Diabetes Metab. 2011; 37(1):72-8. [PubMed: 21126900]

11. Utzschneider KM, Prigeon RL, Faulenbach MV, Tong J, Carr DB, Boyko EJ, et al. Oral disposition index predicts the development of future diabetes above and beyond fasting and 2-h glucose levels. Diabetes Care. 2009; 32(2):335-41. [PubMed: 18957530]

12. Jeffery AN, Metcalf BS, Hosking J, Streeter AJ, Voss LD, Wilkin TJ. Age Before Stage: Insulin Resistance Rises Before the Onset of Puberty: A 9-year longitudinal study (EarlyBird 26). Diabetes Care. 2012; 35(3):536-41. [PubMed: 22279034] 
13. Nadeau KJ, Zeitler PS, Bauer TA, Brown MS, Dorosz JL, Draznin B, et al. Insulin resistance in adolescents with type 2 diabetes is associated with impaired exercise capacity. J Clin Endocrinol Metab. 2009; 94(10):3687-95. [PubMed: 19584191]

14. George L, Bacha F, Lee S, Tfayli H, Andreatta E, Arslanian S. Surrogate estimates of insulin sensitivity in obese youth along the spectrum of glucose tolerance from normal to prediabetes to diabetes. J Clin Endocrinol Metab. 2011; 96(7):2136-45. [PubMed: 21508130]

15. Pacini G. The hyperbolic equilibrium between insulin sensitivity and secretion. Nutr Metab Cardiovasc Dis. 2006; 16(Suppl 1):S22-7. [PubMed: 16530125]

16••. Sjaarda LG, Bacha F, Lee S, Tfayli H, Andreatta E, Arslanian S. Oral disposition index in obese youth from normal to prediabetes to diabetes: relationship to clamp disposition index. J Pediatr. 2012; 161(1):51-7. [PubMed: 22325254] This was a prospectice study that examined the relationship between a hyper-insulinemic clamp, a hyperglycemic clamp and an OGTT. The disposition index from the OGTT was similar to that from the clamp in youth.

17. Lyssenko V, Almgren P, Anevski D, Perfekt R, Lahti K, Nissen M, et al. Predictors of and longitudinal changes in insulin sensitivity and secretion preceding onset of type 2 diabetes. Diabetes. 2005; 54(1):166-74. [PubMed: 15616025]

18. Schwartz B, Jacobs DR Jr, Moran A, Steinberger J, Hong CP, Sinaiko AR. Measurement of insulin sensitivity in children: comparison between the euglycemic-hyperinsulinemic clamp and surrogate measures. Diabetes Care. 2008; 31(4):783-8. [PubMed: 18174496]

19•. Aradillas-Garcia C, Rodriguez-Moran M, Garay-Sevilla ME, Malacara JM, Rascon-Pacheco RA, Guerrero-Romero F. Distribution of the homeostasis model assessment of insulin resistance in Mexican children and adolescents. Eur J Endocrinol. 2012; 166(2):301-6. [PubMed: 22065856] This is a large cross-sectional study of mexican children of all ages and tanner stages, who under went fasting glucose and insulin to caclulate a HOMA score, and proposes age and pubertal based norms for insulin resistance.

20. McLaughlin T, Abbasi F, Cheal K, Chu J, Lamendola C, Reaven G. Use of metabolic markers to identify overweight individuals who are insulin resistant. Ann Intern Med. 2003; 139(10):802-9. [PubMed: 14623617]

21. Dabelea D, D’Agostino RB Jr, Mason CC, West N, Hamman RF, Mayer-Davis EJ, et al. Development, validation and use of an insulin sensitivity score in youths with diabetes: the SEARCH for Diabetes in Youth study. Diabetologia. 2011; 54(1):78-86. [PubMed: 20886205]

22. Weiss R, Dufour S, Taksali SE, Tamborlane WV, Petersen KF, Bonadonna RC, et al. Prediabetes in obese youth: a syndrome of impaired glucose tolerance, severe insulin resistance, and altered myocellular and abdominal fat partitioning. Lancet. 2003; 362(9388):951-7. [PubMed: 14511928]

23. Petersen KF, Hendler R, Price T, Perseghin G, Rothman DL, Held N, et al. 13C/31P NMR studies on the mechanism of insulin resistance in obesity. Diabetes. 1998; 47(3):381-6. [PubMed: 9519743]

24. Kim G, Caprio S. Diabetes and insulin resistance in pediatric obesity. Pediatr Clin North Am. 2011; 58(6):1355-61. ix. [PubMed: 22093855]

25. Nadeau KJ, Ehlers LB, Zeitler PS, Love-Osborne K. Treatment of non-alcoholic fatty liver disease with metformin versus lifestyle intervention in insulin-resistant adolescents. Pediatr Diabetes. 2009; 10(1):5-13. [PubMed: 18721166]

26. Love-Osborne KA, Nadeau KJ, Sheeder J, Fenton LZ, Zeitler P. Presence of the metabolic syndrome in obese adolescents predicts impaired glucose tolerance and nonalcoholic fatty liver disease. J Adolesc Health. 2008; 42(6):543-8. [PubMed: 18486862]

27. Bennett B, Larson-Meyer DE, Ravussin E, Volaufova J, Soros A, Cefalu WT, et al. Impaired insulin sensitivity and elevated ectopic fat in healthy obese vs. nonobese prepubertal children. Obesity (Silver Spring). 2012; 20(2):371-5. [PubMed: 21869763]

28. Perseghin G, Bonfanti R, Magni S, Lattuada G, De Cobelli F, Canu T, et al. Insulin resistance and whole body energy homeostasis in obese adolescents with fatty liver disease. Am J Physiol Endocrinol Metab. 2006; 291(4):E697-703. [PubMed: 16684857]

29. Cali AM, Man CD, Cobelli C, Dziura J, Seyal A, Shaw M, et al. Primary defects in beta-cell function further exacerbated by worsening of insulin resistance mark the development of impaired glucose tolerance in obese adolescents. Diabetes Care. 2009; 32(3):456-61. [PubMed: 19106382] 
30. Turrens JF. Mitochondrial formation of reactive oxygen species. J Physiol. 2003; 552(Pt 2):33544. [PubMed: 14561818]

31. Cree MG, Wolfe RR. Postburn trauma insulin resistance and fat metabolism. Am J Physiol Endocrinol Metab. 2008; 294(1):E1-9. [PubMed: 17957035]

32. Reinehr T, Kiess W, Andler W. Insulin sensitivity indices of glucose and free fatty acid metabolism in obese children and adolescents in relation to serum lipids. Metabolism. 2005; 54(3): 397-402. [PubMed: 15736120]

33. Kelley DE, He J, Menshikova EV, Ritov VB. Dysfunction of mitochondria in human skeletal muscle in type 2 diabetes. Diabetes. 2002; 51(10):2944-50. [PubMed: 12351431]

34. Fleischman A, Kron M, Systrom DM, Hrovat M, Grinspoon SK. Mitochondrial function and insulin resistance in overweight and normal-weight children. J Clin Endocrinol Metab. 2009; 94(12):4923-30. [PubMed: 19846731]

35. Morino K, Petersen KF, Dufour S, Befroy D, Frattini J, Shatzkes N, et al. Reduced mitochondrial density and increased IRS-1 serine phosphorylation in muscle of insulin-resistant offspring of type 2 diabetic parents. J Clin Invest. 2005; 115(12):3587-93. [PubMed: 16284649]

36. Cook JS, Hoffman RP, Stene MA, Hansen JR. Effects of maturational stage on insulin sensitivity during puberty. J Clin Endocrinol Metab. 1993; 77(3):725-30. [PubMed: 7690363]

37. Roemmich JN, Clark PA, Lusk M, Friel A, Weltman A, Epstein LH, et al. Pubertal alterations in growth and body composition. VI. Pubertal insulin resistance: relation to adiposity, body fat distribution and hormone release. Int J Obes Relat Metab Disord. 2002; 26(5):701-9. [PubMed: 12032756]

38. Guercio G, Rivarola MA, Chaler E, Maceiras M, Belgorosky A. Relationship between the growth hormone/insulin-like growth factor-I axis, insulin sensitivity, and adrenal androgens in normal prepubertal and pubertal girls. J Clin Endocrinol Metab. 2003; 88(3):1389-93. [PubMed: 12629134]

39. Travers SH, Jeffers BW, Bloch CA, Hill JO, Eckel RH. Gender and Tanner stage differences in body composition and insulin sensitivity in early pubertal children. J Clin Endocrinol Metab. 1995; 80(1):172-8. [PubMed: 7829608]

40. Wilson AJ, Prapavessis H, Jung ME, Cramp AG, Vascotto J, Lenhardt L, et al. Lifestyle modification and metformin as long-term treatment options for obese adolescents: study protocol. BMC Public Health. 2009; 9:434. [PubMed: 19943971]

41. Modan M, Karasik A, Halkin H, Fuchs Z, Lusky A, Shitrit A, et al. Effect of past and concurrent body mass index on prevalence of glucose intolerance and type 2 (non-insulin-dependent) diabetes and on insulin response. The Israel study of glucose intolerance, obesity and hypertension. Diabetologia. 1986; 29(2):82-9. [PubMed: 3516770]

42. Sakurai Y, Teruya K, Shimada N, Umeda T, Tanaka H, Muto T, et al. Association between duration of obesity and risk of non-insulindependent diabetes mellitus. The Sotetsu Study. Am J Epidemiol. 1999; 149(3):256-60. [PubMed: 9927221]

43. Everhart JE, Pettitt DJ, Bennett PH, Knowler WC. Duration of obesity increases the incidence of NIDDM. Diabetes. 1992; 41(2):235-40. [PubMed: 1733815]

44. Lee JM, Gebremariam A, Vijan S, Gurney JG. Excess body mass index-years, a measure of degree and duration of excess weight, and risk for incident diabetes. Arch Pediatr Adolesc Med. 2012; 166(1):42-8. [PubMed: 22213749]

45. Dietz WH. Health consequences of obesity in youth: childhood predictors of adult disease. Pediatrics. 1998; 101(3 Pt 2):518-25. [PubMed: 12224658]

46. Brotman LM, Dawson-McClure S, Huang KY, Theise R, Kamboukos D, Wang J, et al. Early childhood family intervention and long-term obesity prevention among high-risk minority youth. Pediatrics. 2012; 129(3):e621-8. [PubMed: 22311988]

47. Kimm SY, Glynn NW, Kriska AM, Fitzgerald SL, Aaron DJ, Similo SL, et al. Longitudinal changes in physical activity in a biracial cohort during adolescence. Med Sci Sports Exerc. 2000; 32(8):1445-54. [PubMed: 10949011]

48. Fagot-Campagna A. Emergence of type 2 diabetes mellitus in children: epidemiological evidence. J Pediatr Endocrinol Metab. 2000; 13(Suppl 6):1395-402. [PubMed: 11202215] 
49. Urakami T, Habu M, Kuwabara R, Komiya K, Nagano N, Suzuki J, et al. Insulin resistance at diagnosis in Japanese children with type 2 diabetes mellitus. Pediatr Int. 2012; 54(4):516-9. [PubMed: 22360541]

50. Wei M, Gibbons LW, Mitchell TL, Kampert JB, Lee CD, Blair SN. The association between cardiorespiratory fitness and impaired fasting glucose and type 2 diabetes mellitus in men. Ann Intern Med. 1999; 130(2):89-96. [PubMed: 10068380]

51. Laaksonen DE, Lindstrom J, Lakka TA, Eriksson JG, Niskanen L, Wikstrom K, et al. Physical activity in the prevention of type 2 diabetes: the Finnish diabetes prevention study. Diabetes. 2005; 54(1):158-65. [PubMed: 15616024]

52•. Henderson M, Gray-Donald K, Mathieu ME, Barnett TA, Hanley JA, O’Loughlin J, et al. How are physical activity, fitness, and sedentary behavior associated with insulin sensitivity in children? Diabetes Care. 2012; 35(6):1272-8. [PubMed: 22492585] This was a prospective cohort study examine physcial fitness, percent body fat, and activity in children with 1 obese parent. Moderate to vigorous activity and sedentary behaviors were associated with percent body fat and insulin sensitivity.

53. Group TS, Zeitler P, Hirst K, Pyle L, Linder B, Copeland K, et al. A clinical trial to maintain glycemic control in youth with type 2 diabetes. N Engl J Med. 2012; 366(24):2247-56. [PubMed: 22540912]

54. Centers for Disease Control and Prevention. Trends in intake of energy and macronutrients-United States, 1971-2000. MMWR Morb Mortal Wkly Rep. 2004; 53(4):80-2. [PubMed: 14762332]

55. Esmaillzadeh A, Kimiagar M, Mehrabi Y, Azadbakht L, Hu FB, Willett WC. Dietary patterns, insulin resistance, and prevalence of the metabolic syndrome in women. Am J Clin Nutr. 2007; 85(3):910-8. [PubMed: 17344515]

56. Esmaillzadeh A, Kimiagar M, Mehrabi Y, Azadbakht L, Hu FB, Willett WC. Fruit and vegetable intakes, C-reactive protein, and the metabolic syndrome. Am J Clin Nutr. 2006; 84(6):1489-97. [PubMed: 17158434]

57. Sahyoun NR, Jacques PF, Zhang XL, Juan W, McKeown NM. Whole-grain intake is inversely associated with the metabolic syndrome and mortality in older adults. Am J Clin Nutr. 2006; 83(1):124-31. [PubMed: 16400060]

58. Esposito K, Marfella R, Ciotola M, Di Palo C, Giugliano F, Giugliano G, et al. Effect of a mediterranean-style diet on endothelial dysfunction and markers of vascular inflammation in the metabolic syndrome: a randomized trial. JAMA. 2004; 292(12):1440-6. [PubMed: 15383514]

59. Dorgan JF, Liu L, Barton BA, Deshmukh S, Snetselaar LG, Van Horn L, et al. Adolescent diet and metabolic syndrome in young women: results of the Dietary Intervention Study in Children (DISC) follow-up study. J Clin Endocrinol Metab. 2011; 96(12):E1999-2008. [PubMed: 21994964]

60. Willi SM, Martin K, Datko FM, Brant BP. Treatment of type 2 diabetes in childhood using a verylow-calorie diet. Diabetes Care. 2004; 27(2):348-53. [PubMed: 14747212]

61. Gillman MW, Rifas-Shiman S, Berkey CS, Field AE, Colditz GA. Maternal gestational diabetes, birth weight, and adolescent obesity. Pediatrics. 2003; 111(3):e221-6. [PubMed: 12612275]

62. Brumbaugh DE, Cree-Green M, Alston M, Hoffman MC, Reynolds RM, Friedman JE, et al. Maternal pre-pregnancy BMI influences hepatic fat storage in neonates. J Dev Orig Health Dis. 2011; 2(S1):S35-150.

63. Borgono CA, Hamilton JK, Ye C, Hanley AJ, Connelly PW, Sermer M, et al. Determinants of insulin resistance in infants at age 1 year: impact of gestational diabetes mellitus. Diabetes Care. 2012; 35(8):1795-7. [PubMed: 22699283]

64. Crume TL, Bahr TM, Mayer-Davis EJ, Hamman RF, Scherzinger AL, Stamm E, et al. Selective protection against extremes in childhood body size, abdominal fat deposition, and fat patterning in breastfed children. Arch Pediatr Adolesc Med. 2012; 166(5):437-43. [PubMed: 22566544]

65. Defronzo RA. Banting Lecture. From the triumvirate to the ominous octet: a new paradigm for the treatment of type 2 diabetes mellitus. Diabetes. 2009; 58(4):773-95. [PubMed: 19336687]

66. Kahn SE, Hull RL, Utzschneider KM. Mechanisms linking obesity to insulin resistance and type 2 diabetes. Nature. 2006; 444(7121):840-6. [PubMed: 17167471] 
67. Brufani C, Ciampalini P, Grossi A, Fiori R, Fintini D, Tozzi A, et al. Glucose tolerance status in 510 children and adolescents attending an obesity clinic in Central Italy. Pediatr Diabetes. 2010; 11(1):47-54. [PubMed: 19460122]

68. Weiss R, Caprio S, Trombetta M, Taksali SE, Tamborlane WV, Bonadonna R. Beta-cell function across the spectrum of glucose tolerance in obese youth. Diabetes. 2005; 54(6):1735-43.

[PubMed: 15919795]

69••. Kleber M, Lass N, Papcke S, Wabitsch M, Reinehr T. One-year follow-up of untreated obese white children and adolescents with impaired glucose tolerance: high conversion rate to normal glucose tolerance. Diabet Med. 2010; 27(5):516-21. [PubMed: 20536946] 79 children with IGT were examined with an OGTT at baseline and a year later. A year later, $66 \%$ had convered to NGT, 33\% were still IGT, and one had progressed to T2DM.

70. Gungor N, Arslanian S. Progressive beta cell failure in type 2 diabetes mellitus of youth. J Pediatr. 2004; 144(5):656-9. [PubMed: 15127006]

71. Lyssenko V, Jonsson A, Almgren P, Pulizzi N, Isomaa B, Tuomi T, et al. Clinical risk factors, DNA variants, and the development of type 2 diabetes. N Engl J Med. 2008; 359(21):2220-32. [PubMed: 19020324]

72. Salgin B, Ong KK, Thankamony A, Emmett P, Wareham NJ, Dunger DB. Higher fasting plasma free Fatty Acid levels are associated with lower insulin secretion in children and adults and a higher incidence of type 2 diabetes. J Clin Endocrinol Metab. 2012; 97(9):3302-9. [PubMed: 22740706]

73. Pozzilli P, Guglielmi C, Caprio S, Buzzetti R. Obesity, autoimmunity, and double diabetes in youth. Diabetes Care. 2011; 34(Suppl 2):S166-70. [PubMed: 21525450]

74. Taha D, Umpaichitra V, Banerji MA, Castells S. Type 2 diabetes mellitus in African-American adolescents: impaired beta-cell function in the face of severe insulin resistance. J Pediatr Endocrinol Metab. 2006; 19(2):135-42. [PubMed: 16562586]

75. Burns SF, Bacha F, Lee SJ, Tfayli H, Gungor N, Arslanian SA. Declining beta-cell function relative to insulin sensitivity with escalating OGTT 2-h glucose concentrations in the nondiabetic through the diabetic range in overweight youth. Diabetes Care. 2011; 34(9):2033-40. [PubMed: 21750275]

76. Tfayli H, Lee SJ, Bacha F, Arslanian S. One-hour plasma glucose concentration during the OGTT: what does it tell about beta-cell function relative to insulin sensitivity in overweight/obese children? Pediatr Diabetes. 2011; 12(6):572-9. [PubMed: 21466647]

77•. Giannini C, Weiss R, Cali A, Bonadonna R, Santoro N, Pierpont B, et al. Evidence for early defects in insulin sensitivity and secretion before the onset of glucose dysregulation in obese youths: a longitudinal study. Diabetes. 2012; 61(3):606-14. [PubMed: 22315322] 60 obese children who were NGT with an OGTT and a hyperinsulinemic clamp are baseline were restudied 2 years later, and found to have a decline in beta cell function, prior to the development of hyperglycemia.

78. Nowicka P, Santoro N, Liu H, Lartaud D, Shaw MM, Goldberg R, et al. Utility of hemoglobin $\mathrm{A}(1 \mathrm{c})$ for diagnosing prediabetes and diabetes in obese children and adolescents. Diabetes Care. 2011; 34(6):1306-11. [PubMed: 21515842]

79. Weiss R, Taksali SE, Tamborlane WV, Burgert TS, Savoye M, Caprio S. Predictors of changes in glucose tolerance status in obese youth. Diabetes Care. 2005; 28(4):902-9. [PubMed: 15793193]

80. Kleber M, deSousa G, Papcke S, Wabitsch M, Reinehr T. Impaired glucose tolerance in obese white children and adolescents: three to five year follow-up in untreated patients. Exp Clin Endocrinol Diabetes. 2011; 119(3):172-6. [PubMed: 20827664] 

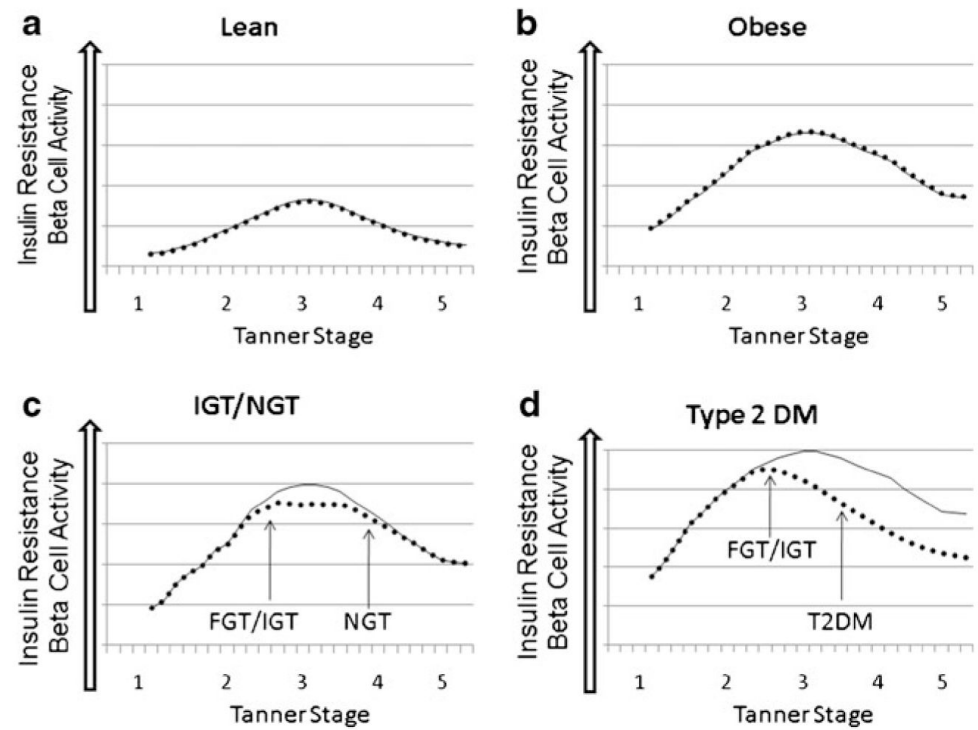

Fig. 1.

Patterns of insulin resistance and pancreatic beta-cell function throughout puberty. Proposed patterns of insulin resistance and beta-cell function are shown for different populations of children. $\bullet \bullet \bullet$ Denotes beta-cell function, and - Insulin resistance in all graphs. a In lean children, there is a modest increase in insulin resistance as they progress through puberty, which is matched by pancreatic insulin secretions. $\mathbf{b}$ The same is seen in obese children with NGT, although they are more IR, with matched increases in insulin release. $\mathbf{c}$ In obese children who become NGT or IGT, as they progress through puberty, they return to an NGT state, but maybe at risk for redevelopment of IGT/FGT when they face another physiologic stressor. $\mathbf{d}$ In obese children who progress to developing diabetes, they develop IGT/FGT first, and then have continued insulin deficiency, and cannot compensate for their degree of IR, even as they progress to adulthood 